\title{
Evaluasi Pembelajaran Mata Kuliah Bahasa Indonesia di Masa Pandemik Pada Mahasiswa PGSD
}

\author{
Lutfi ${ }^{*}$, Muchlas Susesno ${ }^{2}$, Syamsi Setiadi ${ }^{3}$ \\ 1 Universitas Muhammadiyah Jakarta, Universitas Negeri Jakarta, Bogor, Indonesia \\ 2Universitas Negeri Jakarta, Jakarta, Indonesia \\ ${ }^{3}$ Universitas Negeri Jakarta, Jakarta, Indonesia \\ *Corresponding author: lutvpackot@gmail.com, lutfi_9906921002@mhs.unj.ac.id
}

\begin{abstract}
Evaluation of Indonesian language learning in PGSD FIP UMJ students boldly by paying attention to the steps of evaluating online-based Indonesian language learning including planning and implementation. This study also found that students did not understand the Indonesian language learning process at all. With these findings, lecturers make innovations in teaching and learning. The application of online-based Indonesian learning that has been carried out during the pandemic is going well and effectively. There is progress from the tasks that have been carried out. The existence of a bold learning process in Indonesian language learning is expected to help achieve the goals and success in this courage-based Indonesian language learning process, and can improve and add insight into the Indonesian language itself.

Keywords: indonesian language; learning evaluation
\end{abstract}

\begin{abstract}
ABSTRAK
Evaluasi pembelajaran bahasa Indonesia pada mahasiswa PGSD FIP UMJ secara daring dengan memperhatikan langkah-langkah evaluasi pembelajaran bahasa bahasa Indonesia berbasis online meliputi perencanaan serta pelaksanaan. Metode yang diambil ialah penelitian kualitatif. Penelitian kualitatif ialah penelitian yang mendapatkan data deskriptif berbentuk kata-kata tertulis dan lisan dari responden yang bisa simak dengan baik. Penelitian ini juga mendapat temuan bahwa mahasiswa yang tidak paham sama sekali pada proses pembelajaran bahasa Indonesia. Dengan adannya temuan tersebut, hendaknya dosen melakukan inovasi dalam pengajaran dan pembelajaran. Penerapan pembelajaran Bahasa Indonesia berbasis online yang telah dilakukan selama pandemi berlangsung ini adalah baik dan efektif. Adanya progres dari tugas yang sudah dilaksanakan. Proses pembelajaran secara daring pembelajaran bahasa Indonesia ini diharapkan dapat membantu tercapainya tujuan dan keberhasilan dalam proses pelakasanaan pembelajaran bahasa Indonesia berbasis daring ini, serta dapat meningkatkan dan menambahkan wawasan tentang bahasa Indonesia itu sendiri untuk mengukur tingkat keberhasilan pembelajaran bahasa Indonesia secara efektif dengan cara sistematis serta berkesinambungan untuk mengetahui gambaran kemampuan mahasiswa.
\end{abstract}

Kata Kunci: bahasa Indonesia; evaluasi pembelajaran

\section{Pendahuluan}

Perubahan aktivitas semua manusia diberbagai negara, suku, bahkan agama adalah karena Covid 19 yang sudah mewabah (Sawitri, 2020) Berbagai bidang terkena dampak covid 19, diantaranya yang terkena adalah bidang pendidikan, siswa dan guru, mahasiswa dan dosen melakukan pembelajaran secara daring (dalam jaringan) atau sering disebut pembelajaran online Ismawati dan Prasetyo, 2020) Jenjang pendidikan apapun "dipaksa" beralih dan membiasakan diri secara drastis melakukan pembelajaran menggunakan prangkat elektronik dan teknologi yang ada. Teknologi yang kurang maju dan harus ada membuat kegiatan tersebut tidaklah mudah sepeti membalikan telapak tangan (Zahra dan Wijayanti, 2020) 
Pada lain hal, sejumlah permasalahan dan kesulitan terus membayangi hal tersebut dianggap untuk hal penting mengubah sistem pendidikan menuju digital (Gusty, 2020). Wabah Covid -19 sebuah persoalan yang multidimensi pada masyarakat pelajar, hal yang sama dirasakan akibatnya pada bidang pendidikan yang membuat anjoknya kualitas belajar pada mahasiswa atau peserta didik (Sakina dkk, 2021) Wabah covid-19 mengubah semua konsep dan tidak bisa dipungkiri, semua metode pembelajaran dimaksimalkan serta adanya covid-19 ini juga mengubah pembelajaran cara konvensional, yaitu guru, dosen serta peserta didik harus membiasakan pembelajaran daring. sejumlah Aplikasi yang digunakan menunjang pembelajaran yang efektif yang menghaslkan pembelajaran berkualitas (Marbun, 2020).

Untuk menuju pembelajaran yang berkualitas pada mata kuliah Bahasa Indonesia dapat diukur atau dapat diketahui dengan cara evaluasi pembelajaran Bahasa Indonesia secara daring pada mahasiswa PGSD FIP UMJ. Evaluasi tersebut mempunyai tujuan mendapatkan informasi yang berkorelasi dengan mahasiswa dan pembelajaran (Pamuji dan Hidayati, 2021). Dalam kegiatan evaluasi ini diharapkan juga menjadi salah satu nilai yang signifikan sebagai salah satu ukuran keberhasilan pada proses pembelajaran bahasa Indonesia pada mahasiswa serta bisa digunakan sebagai masukkan untuk perbaikan pembelajaran di masa yang akan datang pada pembelajaran bahasa Indonesia yang efektif. Prodi PGSD FIP UMJ adalah salah satu prodi di Universitas Muhammadiyah Jakarta yang memiliki mahasiswa yang banyak dan sudah memiliki predikan prodi unggul dan selalu mengembangkan disemua aspek untuk tetap unggul, yang menjadikan mata kuliah penelitian adalah pembelajaran bahasa Indonesin, dikarenakan banyak mahasiswa setelah mengikuti pembelajaran tersebut masih banyak yang tidak menggunakan ilmu yang berkaitan dengan penulisan dan lain-lain. Dosen Bahasa Indonesia melakukan pembelajaran online melalui whatsapp (sebagai komunikasi), LMS (Ecampus.fipumj), serta video converence zoom meeting dan Google Meet serta lain-lain.

Diakhir pembelajaran dan diakhir semester peneliti melakukan evaluasi pembelajaran bahasa Indonesia, temuannya adalah ada mahasiswa yang tidak paham terhadap yang apa yang sudah didiskusikan selama proses pembelajaran, sehingga membuat peneliti untuk melakukan evaluasi sebagai tolak ukur keberhasilan pada proses pembelajaran yang bertujuan menentukan dan membuat keputusan awal dalam penelitian bisa terwujud berdasarkan pembelajaran yang ideal dan efektif. Alat yang digunakan sebagai penelitian adalah berupa tes soal bahasa Indonesia yang pernah didiskusikan di kelas dengan dosen, kuesioner, wawancara secara keseluruhan pada mahasiswa yang mengikuti proses pembelajaran mata kuliah Bahasa Indonesia, dan observasi (Nuriyah, 2014). Secara umum hasil evaluasi dari proses belajar dikatakan baik, peneliti melakukan evaluasi terhadap mahasiswa, maka peneliti bisa mengambil seluruh objek dengan bahan evaluasi (Suardipa dan Primayana, 2020). Perolehan hasil evaluasi akan dikorelasikan dengan evaluasi sebelumnya sebeb pembelajaran bahasa bahasa Indonesia saja adalah suatu proses yang berkesinambungan dalam menarik kesimpulan mengenai evaluasi.

Pendapat lain penelitian harus memiliki prinsip objektif yaitu peneliti mengevaluasi keseluruhan tanpada memilah-milih (Indriana, 2018). Sebab itu, untuk mengukur tingkat keberhasilan pembelajaran bahasa Indonesia secara efektif dengan cara sistematis serta berkesinambungan untuk mengetahui gambaran kemampuan mahasiswa yang dievaluasi Oleh karena itu, tujuan penelitian ini memokuskan pada pelaksanaan evaluasi pembelajaran 
bahasa Indonesia pada mahasiswa PGSD FIP UMJ tahun ajar 2020/2021 serta dapat mengetahui hasil belajar mahasiswa selama proses pembelajaran bahasa Indonesia di semester satu.

\section{Metode Penelitian}

Metode yang diambil ialah penelitian kualitatif. Zulfitria (2021:57) Penelitian ini menggunakan metode kualitatif dengan tolak ukurnya sebuah analisis deskriptif digunakan sebagai pendekatan pada penelitian ini. analisis deskriptif ialah pengumpulan data secara kaya dari suatu kegiatan/kejadian yang ada untuk dianalisis, dapat diperloah sebuah gambaran yang sudah diteliti. Kata-kata, gambar, dokumen dan tingkah laku yang dikumpulkan oleh peneliti (Zainal Arifin, 2017). Mahasiswa PGSD FIP UMJ yang sudah mengikuti mata kuliah bahasa Indonesia. Teknik pengumpulan data dalam penelitian ini ialah Dokumentasi ialah teknik pengumpulan data dalam menghimpun serta menganalisis dokumen-dokumen, baik dokumen tertulis, gambar maupun elektronik. Dokumen-dokumen yang dihimpun dipilih yang sesuai dengan tujuan dan fokus masalah (Sukmadinata, 2011). Metode ini digunakan untuk memperoleh data mengenai daftar-daftar nama mahasiwa dan hasil belajar dengan materi Wawancara adalah suatu bentuk komunikasi verbal jadi semacam percakapan bertujuan untuk memperoleh informasi (Nasution S, 2007). Metode ini digunakan mewawancarai Desain Bahasa Indoesia tersebut untuk mengetahui pelaksanaan evaluasi pembelajaran. PGSD FIP UMJ ialah prodi yang berada di Fakultas Ilmu Pendidikan UMJ yang beralamat di Cireunde, Ciputat Timur, Tangerang Selatan Banten, serta sudah mendapat nilai akreditasi unggul yang menjadikan mahasiswanya menjadi pendidikan yang profesional, islami, dan moderen

\section{Hasil dan Pembahasan}

Pembelajaran yang efektif adalah pembelajaran yang harus dievaluasi dengan baik (Widiyawati dkk, 2020). Proses evaluasi dan pemilihan alat evaluasi sangat berpengaruh dengan data kemampuan mahasiswa atau data kesulitan mahasiswa pada proses belajar bahasa Indonesia. Sebab itu, kecermatan penyusunan alat evaluasi, supaya dapat digunakan sebagai mestinya. Uji coba baik secara sistem dan kepada ahli evaluasi harus dilakukan untuk persyaratan validitas, reliabilitas, daya pembeda, tingkat kesukaran, dan persyaratan dapat dipenuli dengan baik sebagai alat evaluasi sesuai (Dachliyani, 2019). Pertama mahasiswa PGSD FIP UMJ yang sudah mendapat perkuliahan Bahasa Indonesia yang akan menjadi objek evaluasi".

PGSD FIP UMJ ialah prodi yang berada di Fakultas Ilmu Pendidikan UMJ yang beralamat di Cireunde, Ciputat Timur, Tangerang Selatan Banten, serta sudah mendapat nilai akreditasi unggul yang menjadikan mahasiswanya menjadi pendidikan yang profesional, islami, dan moderen. Bertujuan seberapa efektifnya hasil belajar mahasiswa yang sudah melakukan perkuliahan Bahasa Indonesia. Perkuliahan dilaksanakan secara daring atau secara online dengan aplikasi whatasapp untuk dosen berkomunikasi dengan para mahasiswa, sedangkan Zoom Meeting dan Google Meet (Video Conference), LMS (Ecampus.fip.umj) digunakan oleh dosen sebagai pengumpulkan tugas, absensi, diskusi, materi dll.

Perencanaan evaluasi sebagai langkah awal yang diambil oleh peneliti. Sebab, sangat penting untuk melanjutkan rencana selanjutnya yang dilakukan. Evaluasi dipengaruhi oleh bahan evaluasi. Dilakukan sesuai yang sudah direncanaan dengan langkah yang disusun 
secara sistematis. Untuk mendapat hasil yang maksimal dan tidak harus mengulang kembali. karenanya, seorang peneliti evaluasi harus bisa merencanakan dengan baik. Perencanaan sangat mempengaruhi prose evaluasi yang efektif (Arifin, 2009). Peneliti merencanakan proses evaluasi pembelajaran matakuliah bahasa Indonesia pada mahasiswa PGSD FIP UMJ, memnetukan tujuan, materi, indikator, menyusun kisi-kisi, materi yang akan dievaluasikan pada responden, serta metode mengevaluasinya untuk memenuhi kebutuhan informasi. Penelitian ini, peneliti mengevaluasinya ialah non-tes atau berupa tanyangan video.

Pada tahap kedua, jalanya evaluasi adalah melakukan evaluasi sesuai yang sudah direncanakan sebelumnya. Jenis evaluasi bergantung pada perencanaan evaluasi diawal untuk dilakukan. Seorang penetia akan dipengaruhi oleh jenis evaluasi dari evaluasi yang sudah direncanakan, metode, instrumen, waktu, data sumber, dan sebagainya. Tahap pelaksanaan evaluasi sebagai berikut: kesatu, peneliti memberikan sebuah contoh atau proses pembelajaran dalam bentuk video pembelajaran pada mahasiswa yang berisi materi bahasa Indonesia. Hal ini, peneliti memberikan arahan dan menerangkan materi yang terdapat dalam video tersebut dalm beberapa waktu pada mahasiswa. Kedua, peneliti memberikan materi yang nanntinya mahasiswa hafalkan dan diingat.

Pada hal ini, peneliti memberika materi bertujuan untuk dihafalkan oleh mahasiswa. Ketiga, setelah materi yang diberikan oleh peneliti dan sudah dihafalkan oleh mahasiswa. Selanjutnya adalah, mahasiswa diberikan tugas untuk membuat sebuah video, yang mana di dalam video tersebut mahasiswa harus menerangkan/mempresentasikan materi yang diberikan seperti penetliti berikan. 2. Perolehan evaluasi pembelajaran berbasis online sangat penting bagi program apapun, baik itu program pendidikan, pembelajaran, atau pun pelatihan (Matsna dan Mahyudin, 2012). Evaluasi bertujuan untuk mengetahui apakah program yang sudah dijalankan sudah berjalan baik atau tidak, mengena kepada mahasuswa dengan baik, atau sesuai dengan target/tujuan dari program tersebut, ataukah belum sama sekali. Serta jika terjadi dalam menjalankan program seperti di atas maka responden atau penyampai program akan melakukan evaluasi terhadap pencapaian keberhasilannya perkuliahan. Dengan demikian tidak akan mengulanginya kembali di masa yang akan datang atau untuk peneliti berikutnya mempunyai kelebihan.

Tingkat keberhasilan suatu pembelajaran dapat dilakukan evaluasi dengan memperhatikan dan menyimak materi yang sudah dibsampaikan oleh dosen (Damanik dan Zuhdi, 2020). Jika mahasiswa memperoleh hasil yang baik, sudah pasti kepuasan ini ingin didapat kembali pada waktu yang lain. Untuk itu mahasiswa termotivasi untuk belajar lebih giat dan smenagat agar perolehannya minimal sama bahkan meningkat pada masa depan. Tidak heran akan terjadi pada tingkat selanjutnya, setelah memperoleh hasil yang maksimal atau memuaskan mahasiswa tidak lagi rajin belajar. sehingga pada waktu berikutnya hasilnya tidak memuasakan atau bahkan jelek. Perolehan bagi mahasiswa yang tidak memuaskan Jika mahasiswa memperoleh hasil yang tidak memuaskan, maka dapat dipastika di masa yang akan datang akan mendapat sama.

Sebab itu, mahasiswa akan belajar dengan giat. Tetapi bagi mahasiswa yang kurang motivasi atau kurangnya keahlian akan memperloh keputusasaan. Adapun untuk hasil evaluasi pembelajaran berbasis online pada mahasiswa PGSD FIP UMJ , Yang mana rata-rata nilai dari mahasiswa PGSD FIP UMJ adalah 61-79 sebanyak 23 orang, yang mana dengan predikat C. Sedangkan untuk yang di bawah rata-rata terdapat sebanyak 4 orang dengan nilai 
kurang dari 60, yang mana predikat D. Sedangkan untuk nilai 80-89 dengan predikat B ini hanya 2 orang saja. Dan untuk predikat A atau sangat baik ini dengan nilai 90-100 terdapat 1 orang mahasiswa saja yang mendapatkan predikat A ini. Dari hasil penelitian di atas, bahwa pembelajaran secara online ini efektif. Akan tetapi, masih banyak kekurangan dan susahnya untuk mengontrol mahasiswa untuk mengerjakan tugas atau dalam pembelajarannya itu sendiri. Evaluasi ini, berguna memperbaiki pembelajaran selanjutnya pada mahasiswa PGSD FIP UMJ. Serta bertujuan untuk mengetahui efektif atau tidaknya suatu sistem pembelajaran yang diterapkan oleh dosen.

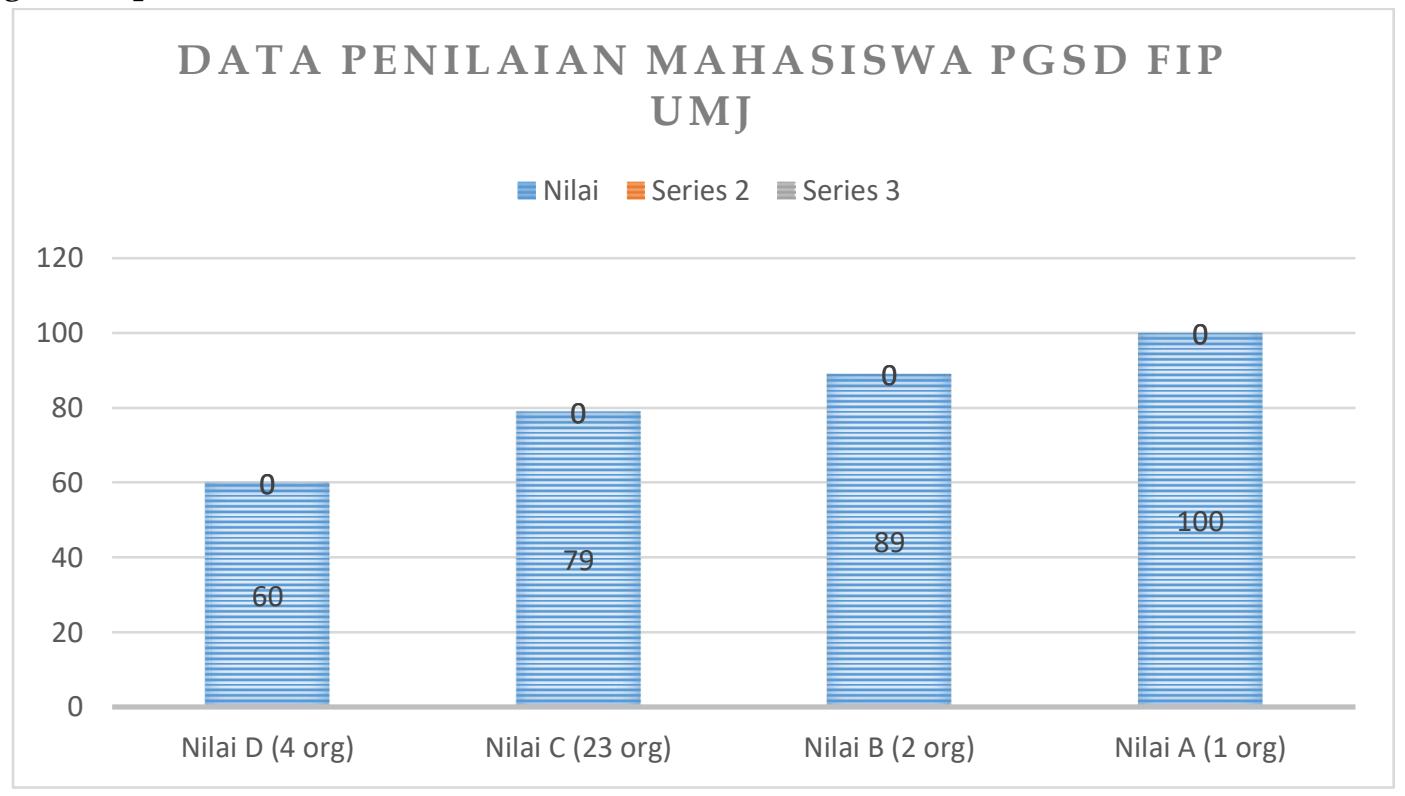

Gambar 1. Diagram Penilaian Mahasiswa PGSD FIP UMJ

Jika seorang peneliti melakukan evaluasi, sama saja tenaga pendidik tersebut tidak ada perkembangan dalam merancang sistem pembelajaran. Dosen Inovasi baru untuk memperbaharui sistem pembelajaran yang akan diterapkan di dalam kelas selanjutnya, mulai dari materi, metode, media, sumber belajar, lingkungan dan sistem penilaian. Dalam merancang evaluasi pembelajaran, dosen juga harus memperhatikan prinsip dasar evaluasi.

Sama halnya yang disampaikan oleh Kuntarto (2017:101) “ketika ingin mengevaluasi hasil belajar siswa atau mahasiswa harus mempersiapkan segala yang diperlukan salah satunya adlaah materi, metode, media, sumber belajar, dan lingkusngan sistem pendidikan. Jd dari hasil penelitian yang dilakukan pada mahasiswa PGSD FIP UMJ bahwa ketika melakukan evaluasi harus mengiliki Inovasi baru untuk memperbaharui sistem pembelajaran yang akan diterapkan di dalam kelas selanjutnya, mulai dari materi, metode, media, sumber belajar, lingkungan dan sistem penilaian yang berlaku. 


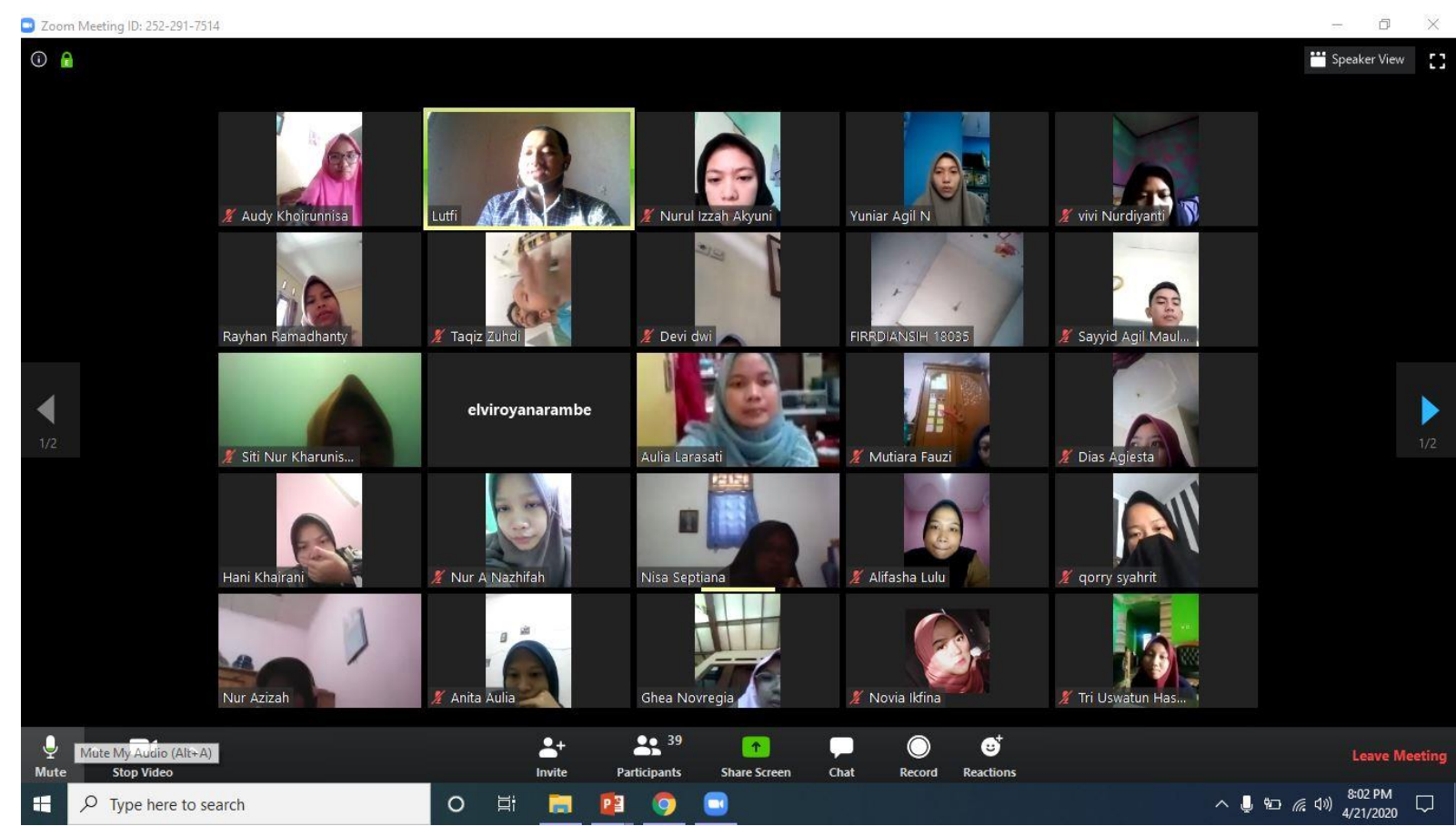

Gambar 2. Proses Evaluasi pembelajaran Bahasa Indonesia pada Mahasiswa PGSD FIP UMJ

\section{Kesimpulan}

Evaluasi adalah pencapaian proses yang suda direncanakan untuk mendapat predikat unggul dalam tercapainya tujuan. evaluasi merupakan sebuah proses pencarian dan pemberian informasi yang sangat bermanfaat bagi pengambil keputusan dalam menentukan alternative keputusan. Evaluasi pembelajaran bahasa Indonesia pada mahasiswa PGSD FIP UMJ secara online. Langkah-langkah evaluasi pembelajaran bahasa bahasa Indonesia berbasis online meliputi: Perencanaan serta pelaksanaan. Penelitian ini juga menguak mahasiswa yang tidak paham sama sekali dalam proses pembelajaran. Dengan dilihat adannya hasil yang seperti itu, hendaknya dosen melakukan inovasi dalam pengajaran dan pembelajaran. Penerapan pembelajaran bahasa Bahasa Indonesia berbasis online yang telah dilakukan pada beberapa pertemuan. Adanya progres dari tugas yang sudah dilaksanakan. Diharapkan dengan pembelajaran bahasa Indonesia berbasis online ini dapat membantu tercapainya tujuan dan keberhasilan dalam proses pelakasanaan pembelajaran bahasa Indonesia berbasis online.

\section{Daftar Pustaka}

Arifin, Z. (2009). Penelitian Pendidian Metode dan Paradigma Baru. Bandung: PT Remaja Rosdakarya.

Dachliyani, L. (2019). “Instrumen Yang Sahih : Sebagai Alat Ukur Keberhasilan Suatu Evaluasi Program Diklat (Evaluasi Pembelajaran)”. Madika, Vol 5, No 1. 
Damanik, S dan Muhammad Zuhdi, M. (2020) “Model Evaluasi Pembelajaran Aud Berbasis Daring Di Ra Nurun Namirah Medan Marelan (Studi Kasus Selama Masa Pandemi Covid-19). Al-Fatih, Vol. 3, No. 1, Doi: Https://Doi.Org/10.30821/Alfatih.V3i1.84.

Farida, I. (2017). Evaluasi Pembelajaran Berdasarkan Kerikulum Nasional. Bandung: PT Remaja Rosdakara.

Gusty, S. (2020). "Belajar Mandiri: Pembelajaran Daring di tengah Pandemi Covid-19”, Yayasan Kita Menulis, H.59.

Ilmiani, A. At all. (2020). Multimedia Interaktif untuk Mengatasi Problematika Pembelajaran Bahasa Arab. Al-Ta'rib: Jurnal Ilmiah Program Studi Pendidikan Bahasa Arab IAIN Palangka Raya, 8(1), 17-32. https:/ / doi.org/10.23971/altarib.v8i1.1902

Indriana, D. (2018) "Evaluasi Pembelajaran dan Penilaian Autentik dalam Pembelajaran Bahasa Arab". Al-ittijah, Vol.10, No. 02.

Kuntarto, E. (2017). Keefektifan Model Pembelajaran Daring dalam Perkuliahan Bahasa Indonesia di Perguruan Tinggi. https://web.archive.org/web/20180411023514id_/http://syekhnurjati.ac.id/jurnal/in dex.php/jeill/article/viewFile/1820/1450

Marbun, P. (2020). “Disain Pembelajaran Online Pada Era Dan Pasca Covid-19”. CSRID Journal 12 (2) .129-142. https:/ / www.doi.org/10.22303/csrid.12.2.2020.129-142.

Matsna dan Mahyudin, E. (2020). Pengembangan Evaluasi dan Tes Bahasa Arab. Tangerang; Selatan: Alkitabah.

Mubarak, M. R., Wahdah, N., Ilmiani, A. M., \& Hamidah, H. (2020). Zoom Cloud Meeting: Media Alternatif dalam Pembelajaran Maharah Kalam di Tengah Wabah Virus Corona (Covid-19). Arabiyatuna : Jurnal Bahasa Arab, 4(2), 211-226. https://doi.org/10.29240/jba.v4i2.1445

Nasution S., (2007). Metode Research (Penelitian Ilmiah). Jakarta: Bumi Aksara.

Nuriyah, N. (2014) “Evaluasi Pembelajaran: Sebuah Kajian Teori”. Jurnal Edueksos Vol. 3, No. 1, Https://Www.Syekhnurjati.Ac.Id/Jurnal/Index.Php/Edueksos/Article/View/327/ 289.

Pamuji, A.R dan Hidayati, D. (2021). "Model Pengembangan Dan Evaluasi Pembelajaran Bahasa Indonesia Di Mts Karangkajen". Aoej, Vol. 12, No. 1, Doi: https://Doi.Org/10.47200/Aoej.V12i1.438.

Sakina, N., Dkk. (2021). “Evaluasi Pembelajaran Daring Terhadap Mata Kuliah Statistika Ipa Iain Bengkulu". Aoej, Vol. 12, No. 1, Doi: Https://Doi.Org/10.47200/Aoej.V12i1.436.

Sawitri, D. (2020). "Penggunaan Google Meet Untuk Work From Home Di Era Pandemi Coronavirus Disease 2019 (Covid-19)". Jurnal Prioritas : Jurnal Pengabdian Masyarakat, Vol. 2, Nomor : 1 .

Suardipa, I.P., dan Primayana, K.H. (2020). “Peran Desain Evaluasi Pembelajaran Untuk Meningkatkan Kualitas Pembelajaran". Widyacarya, Vol. 4, No. 2.

Widiyawati, D., Putri, C.D., dan Walid, A. (2020). “Evaluasi Pembelajaran Serta Pengaruhnya Terhadap Minat Belajar Pada Mata Pembelajaran Ipa Siswa Kelas Ix Smpn 3 Tanjung Sakti Pumi Lahat Sumatra Selatan". Jurnal Ptk \& Pendidikan, Vol. 6, No. 2, Doi: 10.18592/Ptk.V6i2.4227. 
Zahra, A.S dan Wijayanti, S. (2020). "Efektivitas Pembelajaran Basis Online Di Iain Tulungagung Dengan Adanya Kebijakan Physical Distancing Era Pandemi Covid19". Geram, Vol. 8, No.1, Doi: Https://Doi.Org/10.25299/Geram.2020.Vol8(1).5040.

Zulfitria., Rahmatunnisa, S., Khanza, M. (2021). Penggunaan Metode Bercerita Dalam Pengembangan Kemampuan Kognitif Pada Anak Usia Dini. https://jurnal.umj.ac.id/index.php/YaaBunayya/article/view/9300/5537 